\title{
The impact of knowledge management on innovation performance of small and medium enterprises - An empirical study in Lam Dong province
}

\author{
Pham Quoc Trung ${ }^{1 *}$ Le Minh Hieu² \\ ${ }^{1}$ Ho Chi Minh City University of Technology, Vietnam National University HCMC, \\ Vietnam \\ ${ }^{2}$ Atlantic Limited Company, Vietnam \\ *Corresponding author: pqtrung@hcmut.edu.vn
}

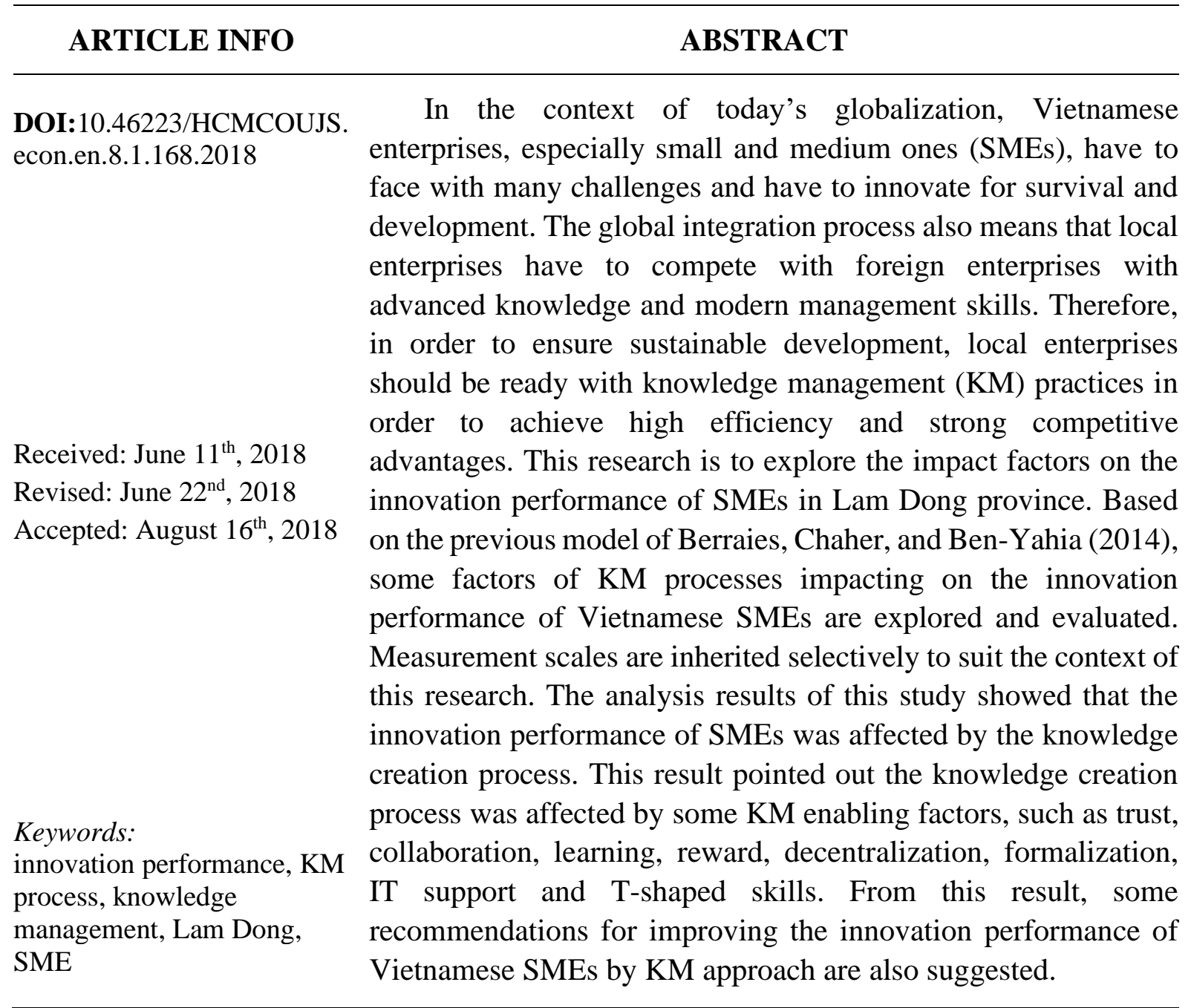

\section{Introduction}

Since the beginning of the $21^{\text {st }}$ century, managers of all enterprises have paid more attention to knowledge and knowledge management because they realized that knowledge is unlimited and it is the only sure source for ensuring the competitive advantages of their businesses (Nonaka \& Takeuchi, 1995). 
Recently, many countries developed their strategies toward the knowledge economy, in which encouraging business innovation is the most important policy for the success of their strategies. According to IPP. (2014), innovation and creativity capability are critical success factors of any business. Especially, technology and management innovation of enterprises are the keys to increase the productivity, improving the business performance, and contributing to the sustainable development of the whole economy. In the knowledge economy, innovation performance is very important for ensuring the success of any business, and KM approach is considered a suitable approach to provide creativity environment and to support the innovation process.

According to the director of the international trade center, Anrancha Gonzalez, SMEs are dynamic, creative and adaptable to the change of market and technology. In the world, SMEs contributed the most for the growth of the economy, helped to create more employment, and to boost the development of the society (Gonzalez, 2014). The rapid development of technology will also support SMEs to become the main factor for innovation in the economy. In fact, there are some SMEs, who could compete strongly with the large ones in the digital world nowadays based on their knowledge and innovation capability.

Currently, Vietnamese SMEs are the majority (about $97 \%$ of all enterprises) and contribute about $1 / 3$ of the total GDP. With the global integration process, Vietnamese SMEs are going to apply KM practices in their businesses for improving innovation capabilities and increasing competitive advantages (Pham, 2013). However, the innovation capability of Vietnamese SMEs is fairly low and the real impacts of KM processes on the innovation performance of Vietnamese SMEs are not measured and confirmed clearly. Besides, in the context of a developing country like Vietnam, there is a lack of research on this topic.

Therefore, the topic "the impact of knowledge management on innovation performance of SMEs - an empirical study in Lam Dong province" is conducted. This research aims at (1) Measuring the impact of KM enabling factors on the knowledge creating process, and then on innovation performance of SMEs in Lam Dong province, and (2) Suggesting some managerial implications for encouraging the knowledge creating process and improving innovation performance of Vietnamese SMEs. The structure of this paper is organized as follows: (2) literature review, (3) research method, (4) analysis results and (5) conclusion and recommendations.

\section{Literature review}

\subsection{Main concepts}

SMEs or small and medium enterprises could be defined differently in manycountries, but in this context, we use a simple definition, which based on the definition of Vietnamese Government - 'SMEs are enterprises with less than 300 full-time employees'. This definition makes SMEs be the most majority of the world economy. Currently, in Lam Dong province, SMEs are about $99 \%$ of all enterprises. Most of them belong to some strong industries of the local market, such as agriculture, forestry, food \& beverage, tourism, and accommodation services. In general, SMEs in Lam Dong province are dynamic, but lack of resources for supporting innovation and sustaining their businesses. As in other areas in Vietnam, the innovation performance of these SMEs is low, and KM approach should be considered an ideal 
solution for improving the innovation performance as well as the overall competitive advantage of Vietnamese SMEs.

Knowledge is defined as "justified belief" (Nonaka \& Takeuchi, 1995). From the viewpoint of cognitive science, knowledge, information and data are related to each other by two dimensions: level of understanding and context independence (Serban \& Luan, 2002). Besides, Polanyi (1966) classified knowledge into two groups: (1) tacit knowledge, which is located in the human brain and difficult to capture, and(2) explicit knowledge, which is easier to capture and to transfer in various forms.

Knowledge management is a process of realizing, sharing, using and practicing knowledge inside of an organization (Choi \& Lee, 2002). For managing knowledge effectively, a knowledge management process should be established. Dalkir (2005) combined previous KM cycles and introduced an integrated KM cycle, including 3 steps: (1) knowledge capture and creation, (2) knowledge sharing and dissemination, and (3) knowledge acquisition and application.

Knowledge creation process (KCP) is proposed by Nonaka and Takeuchi (1995) to explain for the dynamic of the knowledge creating/innovation by the conversion of two main types of knowledge (tacit and explicit) through four main processes, including: socialization, externalization, combination, and internalization. This knowledge creation cycle is also called SECI model.

Knowledge management enabler refers to conditions and organizational environment for supporting KM process and encouraging knowledge creating cycle. According to Nonaka and Takeuchi (1995), supporting conditions for SECI model include: intention, autonomy, creative chaos, redundancy, and requisite variety. According to Berraies et al. (2014), there are five enabling KM factors including: organizational culture, organizational structure, leadership, IT support, and T-shaped skills.

Innovation: according to a definition of the Oxford dictionary, innovation is a process, in which a new product, process, service, or technique is developed. Another definition of Maranville (1992) is as follows: "innovation is a new idea, product or technology, which is perceived by customers by its original or unique quality (Maranville, 1992). There are two main types of innovation: incremental innovation and disruptive innovation (Pham, 2016). Innovation performance is measured by the outcomes of innovation activities, such as patent registration, change or adapt in product, process, manufacturing, and sale...

\subsection{Related researches}

Related researches on KM and innovation performance could be summarized in the following table. 


\section{Table 1}

Related researches in KM and innovation performance

\begin{tabular}{|c|c|c|c|c|}
\hline Author & Sample & Location & Factors & Comments \\
\hline $\begin{array}{l}\text { Lee and } \\
\text { Choi } \\
(2003)\end{array}$ & 58 firms & Korea & $\begin{array}{l}\text { Explore the impact of KM } \\
\text { enablers, KM processes on } \\
\text { Organizational performance. } \\
\text { The model includes: KM } \\
\text { enablers (collaboration, trust, } \\
\text { learning, centralization, } \\
\text { formalization, T- shaped } \\
\text { skills, and information } \\
\text { technology support), } \\
\text { knowledge creation } \\
\text { processes (socialization, } \\
\text { externalization, combination, } \\
\text { and internalization), and } \\
\text { organizational performance. }\end{array}$ & $\begin{array}{l}\text { The results confirmed } \\
\text { the impact of trust on } \\
\text { knowledge creation. The } \\
\text { information technology } \\
\text { support had a positive } \\
\text { impact on knowledge } \\
\text { combination only. } \\
\text { Organizational creativity } \\
\text { was found to be critical } \\
\text { for improving } \\
\text { performance; neglecting } \\
\text { ideas can undermine a } \\
\text { business. }\end{array}$ \\
\hline $\begin{array}{l}\text { Lopez- } \\
\text { Nicolas, } \\
\text { and } \\
\text { Merono- } \\
\text { Cerdan } \\
\text { (2011) }\end{array}$ & $\begin{array}{c}310 \\
\text { companies }\end{array}$ & Spain & $\begin{array}{l}\text { Explore the consequences of } \\
\text { knowledge management (KM) } \\
\text { strategies on firm's innovation } \\
\text { and corporate performance. } \\
\text { Main factors: KM strategies, } \\
\text { innovation, and organizational } \\
\text { performance. }\end{array}$ & $\begin{array}{l}\text { The results show that both } \\
\text { KM strategies } \\
\text { (codification and } \\
\text { personalization) impacts } \\
\text { on innovation and } \\
\text { organizational } \\
\text { performance directly and } \\
\text { indirectly (through an } \\
\text { increase in innovation } \\
\text { capability). } \\
\text { Also, findings demonstrate } \\
\text { a different effect of KM } \\
\text { strategies on diverse } \\
\text { dimensions of } \\
\text { organizational } \\
\text { performance }\end{array}$ \\
\hline $\begin{array}{l}\text { D. Q. } \\
\text { Nguyen } \\
\text { and Vu } \\
(2014)\end{array}$ & $\begin{array}{c}167 \\
\text { companies }\end{array}$ & Vietnam & $\begin{array}{l}\text { Based on the model of Lopez- } \\
\text { Nicolas and Merono-Cerdan } \\
\text { (2011), the research aims to } \\
\text { test the relationship between } \\
\text { strategic knowledge } \\
\text { management, innovation and } \\
\text { firm performance in the } \\
\text { Vietnamese context. Some } \\
\text { main factors: codification KM } \\
\text { strategy, personalization KM } \\
\text { strategy, innovation, and }\end{array}$ & $\begin{array}{l}\text { The results show that } \\
\text { strategic knowledge } \\
\text { management } \\
\text { significantly enhances } \\
\text { innovation and } \\
\text { organizational } \\
\text { performance. Although } \\
\text { codification and } \\
\text { personalization } \\
\text { knowledge management } \\
\text { strategies both have }\end{array}$ \\
\hline
\end{tabular}




\begin{tabular}{|l|l|l|l|l|}
\hline Author & Sample & Location & \multicolumn{1}{|c|}{ Factors } & \multicolumn{1}{c|}{ Comments } \\
\hline & & organizational performance. & $\begin{array}{l}\text { impact on innovation } \\
\text { and performance, } \\
\text { personalization } \\
\text { knowledge management } \\
\text { strategy has the } \\
\text { dominant impact. }\end{array}$ \\
\hline $\begin{array}{l}\text { Berraies } \\
\text { et al. } \\
\text { (2014) }\end{array}$ & companies & Tunisia & $\begin{array}{l}\text { Evaluate the enabling factors } \\
\text { that boost Knowledge } \\
\text { Creation Process (KCP) } \\
\text { within organizations. Some } \\
\text { KM enabling factors include: } \\
\text { collaboration, trust, learning, } \\
\text { incentives and rewards, } \\
\text { decentralized and low } \\
\text { formalized structure, T- } \\
\text { shaped skills, and IT support } \\
\text { and transformational } \\
\text { leadership. }\end{array}$ & $\begin{array}{l}\text { The results reveal that the } \\
\text { best path for Tunisian ICT } \\
\text { companies to foster } \\
\text { knowledge creation is } \\
\text { through incentives and } \\
\text { rewards, collaboration, } \\
\text { trust, learning, } \\
\text { decentralized and low } \\
\text { formalized structure and } \\
\text { IT support. Findings show } \\
\text { also that KCP } \\
\text { significantly affects firms } \\
\text { innovation performance. }\end{array}$ \\
\hline
\end{tabular}

Source: The researcher's data analysis

\subsection{Research model and hypotheses}

Previous researches explored the impact factors of KM on organizational performance in various industries and in different countries. However, the research model of Berraies et al. (2014) is more suitable with the goal of this research when focusing on exploring the relationship between $\mathrm{KM}$ enablers, the knowledge creation process, and innovation performance. Moreover, the developing level of Tunisia companies is similar to Vietnamese ones, so this research model is chosen for testing the impact of KM enablers on the knowledge creation process, and on the innovation performance of SMEs in the context of Vietnam.

This research reuses the framework of Lee and Choi (2003), in which, KM enablers have impacts on KM processes, then, KM processes have impacts on Innovation performance, and finally, Innovation performance has impacts on Organizational performance. However, in order to focus on Innovation performance of SMEs, organizational performance is not mentioned. Besides, SECI model of Nonaka and Takeuchi (1995) is also a base for the relationship between $\mathrm{KCP}$ and innovation performance. According to previous researches (Chatzoudes, Chatzoglou, \& Vraimaki, 2015; Pham \& Nguyen, 2017), organizational culture plays an important role in the performance of businesses, especially SMEs. Therefore, the overall framework for this research could be summarized as follows: KM enablers $=>$ Knowledge creation process $=>$ Innovation performance. Based on Berraies et al. (2014), KM enablers include: organizational culture (trust, collaboration, learning, and reward), transformational leadership, organizational structure (decentralization, formalization), IT support, and T-shaped skills. Besides, the knowledge creation process includes: socialization, externalization, combination, and 
internalization. In summary, the researchmodel could be illustrated in the following figure.

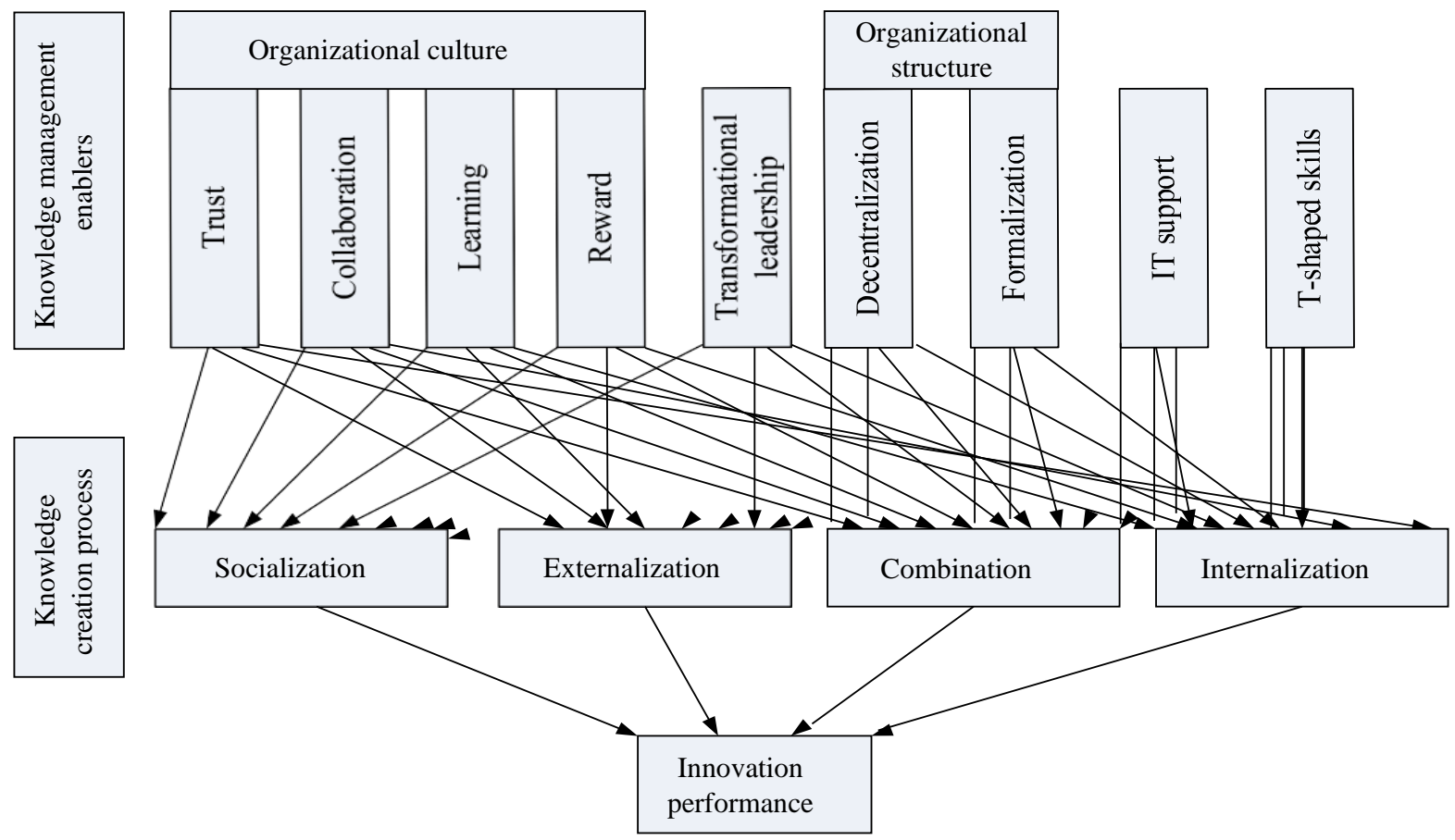

Source: Berraies et al. (2014)

Figure 1. The proposed research model

Based on this research model, hypothesis statements could be summarized as follows:

Trust: Nonaka and Takeuchi (1995) said that trust or belief is very important in the socialization process, especially in sharing tacit knowledge. Lee and Choi (2003) argued that trust, a component of organizational culture, is a need for innovation and creative activities. So, the trust may have a positive impact on knowledge creation processes, and $\mathrm{H} 1, \mathrm{H} 1 \mathrm{a}-\mathrm{H} 1 \mathrm{~d}$ could be stated as follows:

\section{H1: Trust has a positive impact on the knowledge creation process}

Hla: Trust has a positive impact on socialization process

HIb: Trust has a positive impact on externalization process

H1c: Trust has a positive impact on combination process

\section{HId: Trust has a positive impact on internalization process}

Collaboration: Nonaka and Konno (1998) said that the collaboration between employees will support the knowledge creation process. They asked the companies to create a working environment (named "Ba") to boost the interaction and collaboration between knowledge holders and receivers. So, collaboration may have a positive impact on 4 main knowledge creation processes, and $\mathrm{H} 2, \mathrm{H} 2 \mathrm{a}-\mathrm{H} 2 \mathrm{~d}$ could be stated as follows:

H2: Collaboration has a positive impact on knowledge creation process 
H2a: Collaboration has a positive impact on socialization process

H2b: Collaboration has a positive impact on externalization process

H2c: Collaboration has a positive impact on combination process

H2d: Collaboration has a positive impact on internalization process

Learning: Nonaka and Takeuchi (1995) stated that knowledge creation process helps to support continuous learning activities inside and outside of the organization. In order to ensure the success of the knowledge creation process, organizational culture should be changed toward a learning culture (Lee \& Choi, 2003). Al-Hakim and Hassan (2012) proved that learning has a positive impact on knowledge management in the ICT industry in Iraq. The similar results could be found in the context of Korea (Lee \& Choi, 2003), India (Gururajan \& Hafeez-Baig, 2012), and Vietnam (Pham \& Hara, 2011). So, H3, H3a-H3d could be stated as follows:

H3: Learning has a positive impact on knowledge creation process

H2a: Learning has a positive impact on socialization process

$H 2 b$ : Learning has a positive impact on externalization process

H2c: Learning has a positive impact on combination process

H2d: Learning has a positive impact on internalization process

Reward: According to E. Davenport and Hall (2002), a good reward or incentive system of an organization will encourage employees in sharing their knowledge and working experience. Rewards also help to increase productivity. It is considered the external motivation for the knowledge creation process (Charoenngam \& Teerajetgul, 2006). Therefore, H4 and $\mathrm{H} 4 \mathrm{a}-\mathrm{H} 4 \mathrm{~d}$ could be stated as follows:

H4: Reward has a positive impact on knowledge creation process

H4a: Reward has a positive impact on socialization process

H4b: Reward has a positive impact on externalization process

H4c: Reward has a positive impact on combination process

H4d: Reward has a positive impact on internalization process

Transformational leadership: Nonaka and Toyama (2005) emphasized the important role of leadership in communication, knowledge sharing and creating in an organization. Politis (2001) also mentioned the critical impact of transformational leadership on knowledge accumulation. Transformational leadership refers to the way the organization can get benefits based on self-motivations, common ideals, feelings, emotions, or personal styles of leaders (Bass, 1999). Al-Hakim and Hassan (2012) realized the importance of transformational leadership on the success of KM in Iraq. Therefore, $\mathrm{H} 5$ and H5a-H5d could be stated as follows:

H5: Transformational leadership has a positive impact on knowledge creation process

H5a: Transformational leadership has a positive impact on socialization process

H5b: Transformational leadership has a positive impact on externalization process 
H5c: Transformational leadership has a positive impact on combination process

H5d: Transformational leadership has a positive impact on internalization process

Decentralization: According to Lee and Choi (2003), decentralization of organizational structure will encourage autonomy, and improve communication. So, decentralization helps to support four main processes of knowledge creation cycle. Dunk and Jeng (2013) proposed that decentralization has a positive impact on knowledge creation process. Therefore, H6 and H6aH6d could be stated as follows:

H6: Decentralization has a positive impact on knowledge creation process

H6a: Decentralization has a positive impact on socialization process

H6b: Decentralization has a positive impact on externalization process

H6c: Decentralization has a positive impact on combination process

H6d: Decentralization has a positive impact on internalization process

Formalization: According to Lee and Choi (2003), a high formalization of organizational structure will reduce creativity and prevent new ideas. So, formalization may have negative impact on 4 main knowledge creation processes, and $\mathrm{H} 7, \mathrm{H} 7 \mathrm{a}-\mathrm{H} 7 \mathrm{~d}$ could be statedas follows:

H7: Formalization has a negative impact on knowledge creation process

H7a: Formalization has a negative impact on socialization process

H7b: Formalization has a negative impact on externalization process

H7c: Formalization has a negative impact on combination process

H7d: Formalization has a negative impact on internalization process

IT support: According to T. H. Davenport and Prusak (1998), IT helps to increase collaboration ability, boost knowledge creation, and support the decision-making process. Lee and Choi (2003) said that IT supports the knowledge creation process not only in transferring explicit knowledge but also in sharing tacit knowledge. According to Berraies et al. (2014), IT support has a strong impact on socialization, externalization, combination, and internalization in ICT businesses in Tunisia. Therefore, $\mathrm{H} 8$ and H8a-H8d could be stated as follows:

H8: IT support has a positive impact on knowledge creation process

H8a: IT support has a positive impact on socialization process

H8b: IT support has a positive impact on externalization process

H8c: IT support has a positive impact on combination process

H8d: IT support has a positive impact on internalization process

T-shaped skills: Gururajan and Hafeez-Baig (2012) proposed that T-shaped skills have a direct impact on knowledge creating and sharing. Currently, employees with T-shaped skills are valuable resources for business because they have both wide and deep knowledge/skills, which are very useful in solving problems and combining theoretical and practical knowledge. 
Migdadi (2005) also stated that T-shaped skills have a strong impact on knowledge creation process. Therefore, H9 and H9a-H9d could be stated as follows:

H9: T-shaped skills have a positive impact on knowledge creation process

H9a: T-shaped skills have a positive impact on socialization process

H9b: T-shaped skills have a positive impact on externalization process

H9c: T-shaped skills have a positive impact on combination process

H9d: T-shaped skills have a positive impact on internalization process

The knowledge creation process and Innovation performance: Svetina and Prodan (2008) showed that knowledge creating and utilizing have positive impacts on the innovation performance of an organization. Nonaka and Takeuchi (1995) also stated that SECI model helps to boost innovation and creativity in an organization. Lee and Choi (2003) also confirmed that each process in the knowledge creation cycle has a positive impact on organizational innovation performance. Therefore, H10 and H10a-H10d could be stated as follows:

H10: Knowledge creation process has a positive impact on innovation performance

H1Oa: Socialization process has a positive impact on innovation performance

H1Ob: Externalization process has a positive impact on innovation performance

H10c: Combination process has a positive impact on innovation performance

H10d: Internalization process has a positive impact on innovation performance

\section{Research method}

This research is conducted by 2 phases: (1) primary qualitative method for revising measurement scale based on interviews, and (2) quantitative method for testing the model through several tools: Cronbach alpha test, EFA, regression analysis...

The original measurement scales (Table 2) based mostly on Lee and Choi (2003) and Choi and Lee (2002), using 5 levels Likert scale. Some other sources for the measurement scales include: Reward (Charoenngam \& Teerajetgul, 2006), Transformational leadership (Bosch, 2013), and Innovation performance (Svetina \& Prodan, 2008). Then, they are translated into Vietnamese and revised based on interviews with 10 experts in SMEs (8 managers/directors of SMEs in Lam Dong, and 2 researchers). Some main contributions of primary qualitative step could be summarized as follows: remove 1 question in "collaboration" because it is not relevant to SMEs context in Lam Dong, and changing some questions to be more suitable with SMEs, Vietnam culture, and Lam Dong industries. Some minor modifications in spellings, grammars and writing styles have also been made. 
Table 2

Measurement scales of the research model

\begin{tabular}{|c|l|c|c|c|c|}
\hline ID & \multicolumn{1}{|c|}{ Factors } & \multicolumn{1}{|c|}{ Scales } & Sources & $\begin{array}{c}\text { Original } \\
\text { \#Variables }\end{array}$ & $\begin{array}{c}\text { Final } \\
\text { \#Variables }\end{array}$ \\
\hline 1 & Trust & Likert 5 levels & (Lee \& Choi, 2003) & 6 & 6 \\
\hline 2 & Collaboration & Likert 5 levels & (Lee \& Choi, 2003) & 5 & 4 \\
\hline 3 & Learning & Likert 5 levels & (Lee \& Choi, 2003) & 5 & 5 \\
\hline 4 & Reward & Likert 5 levels & (Charoenngam \& & 4 & 4 \\
\hline 5 & $\begin{array}{l}\text { Transformational } \\
\text { leadership }\end{array}$ & Likert 5 levels & (Bosch, 2013) & 7 & 7 \\
\hline 6 & Decentralization & Likert 5 levels & (Lee \& Choi, 2003) & 5 & 5 \\
\hline 7 & Formalization & Likert 5 levels & (Lee \& Choi, 2003) & 5 & 5 \\
\hline 8 & IT support & Likert 5 levels & (Lee \& Choi, 2003) & 5 & 5 \\
\hline 9 & T-shaped skills & Likert 5 levels & (Lee \& Choi, 2003) & 5 & 5 \\
\hline 10 & Socialization & Likert 5 levels & (Choi \& Lee, 2002) & 5 & 5 \\
\hline 11 & Externalization & Likert 5 levels & (Choi \& Lee, 2002) & 4 & 4 \\
\hline 12 & Combination & Likert 5 levels & (Choi \& Lee, 2002) & 5 & 5 \\
\hline 13 & Internalization & Likert 5 levels & (Choi \& Lee, 2002) & 5 & 5 \\
\hline 14 & $\begin{array}{l}\text { Innovation } \\
\text { performance }\end{array}$ & Likert 5 levels & (Svetina \& Prodan, & 5 & 5 \\
\hline
\end{tabular}

Source: The researcher's data analysis

The sample size for the quantitative step must be $>=300$ to be used for data analysis ( $\mathrm{T}$. D. Nguyen \& Nguyen, 2007). The data collection method is a convenience sampling method, with a combination of online and offline surveys. The target respondents are owners, managers (board of directors, head/deputy head of department) of SMEs in Lam Dong province.

Collected data will be processed by SPSS software, through Cronbach's Alpha test, EFA, multiple regression analysis, and hypothesis test.

\section{Analysis results}

\subsection{Descriptive statistics}

The number of questionnaires sent is 650 . The number of questionnaires answered is 383. The number of validated samples (collected from both online and offline) is 29. Descriptive statistics of collected data are summarized in the following table. 


\section{Table 3}

Descriptive statistics of samples by demographic factors

\begin{tabular}{|c|c|c|c|}
\hline Category & Values & Frequency & Percentage \\
\hline \multirow{4}{*}{ Owner type } & Foreign direct investment companies & 15 & $4.56 \%$ \\
\hline & State-owned companies & 23 & $6.99 \%$ \\
\hline & Joint-stock companies & 28 & $8.51 \%$ \\
\hline & Private companies & 263 & $79.94 \%$ \\
\hline \multirow{3}{*}{ Business size } & $<10$ employees & 76 & $23.10 \%$ \\
\hline & $10-<200$ employees & 215 & $65.35 \%$ \\
\hline & $200-<300$ employees & 38 & $11.55 \%$ \\
\hline \multirow{2}{*}{$\begin{array}{l}\text { Respondents' } \\
\text { position }\end{array}$} & Director/ Vice Director & 87 & $26.44 \%$ \\
\hline & Head/ Deputy Head & 242 & $73.56 \%$ \\
\hline \multirow{3}{*}{ Years of experience } & $<5$ years & 45 & $13.68 \%$ \\
\hline & 5 - 10 years & 153 & $46.50 \%$ \\
\hline & $>10$ years & 131 & $39.82 \%$ \\
\hline
\end{tabular}

Source: Data analysis result of the research

The above table showed that most of SMEs in the samples are private companies (80\%), and the majority of business size is less than 200 employees (88\%). Respondents are in the manager/ owner position and most of them have more than 5 years of experience ( $85 \%$ ), which is useful for answering the questionnaire. These numbers are similar to the statistics of SMEs in Vietnam.

\subsection{Cronbach's Alpha analysis}

The below table showed that Cronbach's Alpha coefficients of all factors are reliable (Cronbach's Alpha $>0.6$ ), and after removing 1 item in Formalization factor, all item-total correlation coefficients are satisfied (>0.3). So, all measurement scales could be used for the next step analysis.

\section{Table 4}

Cronbach's Alpha analysis result

\begin{tabular}{|l|c|c|c|}
\hline \multicolumn{1}{|c|}{ Measurement scale } & $\begin{array}{c}\text { Cronbach's } \\
\text { Alpha }\end{array}$ & $\begin{array}{c}\text { Corrected Item- } \\
\text { Total correlations }\end{array}$ & $\begin{array}{c}\text { \#item } \\
\text { removed/remained }\end{array}$ \\
\hline Trust & 0.863 & $0.593-0.713$ & $0 / 6$ \\
\hline Collaboration & 0.727 & $0.306-0.609$ & $0 / 4$ \\
\hline Learning & 0.855 & $0.606-0.739$ & $0 / 5$ \\
\hline Reward & 0.856 & $0.431-0.812$ & $0 / 4$ \\
\hline
\end{tabular}




\begin{tabular}{|l|c|c|c|}
\hline \multicolumn{1}{|c|}{ Measurement scale } & $\begin{array}{c}\text { Cronbach's } \\
\text { Alpha }\end{array}$ & $\begin{array}{c}\text { Corrected Item- } \\
\text { Total correlations }\end{array}$ & $\begin{array}{c}\text { \#item } \\
\text { removed/remained }\end{array}$ \\
\hline Transformational leadership & 0.831 & $0.415-0.756$ & $0 / 7$ \\
\hline Decentralization & 0.878 & $0.633-0.791$ & $0 / 5$ \\
\hline Formalization & 0.847 & $0.594-0.853$ & $1 / 4$ \\
\hline IT support & 0.870 & $0.557-0.792$ & $0 / 5$ \\
\hline T-shaped skills & 0.849 & $0.541-0.785$ & $0 / 5$ \\
\hline Socialization & 0.813 & $0.401-0.744$ & $0 / 5$ \\
\hline Externalization & 0.745 & $0.345-0.620$ & $0 / 4$ \\
\hline Combination & 0.852 & $0.598-0.736$ & $0 / 5$ \\
\hline Internalization & 0.806 & $0.462-0.706$ & $0 / 5$ \\
\hline Innovation performance & 0.824 & $0.425-0.713$ & $0 / 5$ \\
\hline
\end{tabular}

Source: Data analysis result of the research

\subsection{Exploratory Factor Analysis (EFA)}

EFA is used to evaluate the discriminant value and convergence value of the measurement scale. In this research, the factor extraction method is Principle Component and the rotation method is Promax. After removing 13 unqualified variables, exploratory factor analysis for all factors in the proposed model could be grouped into 13 factors. The final EFA result showed that observation variables are satisfied with the model: $\mathrm{KMO}=0.904>0.5$, Bartlett test $\leq 0.05$, sig $=0.000$, and Eigenvalue $>1$, total extracted variance $=62.7 \%>50 \%$ (Hoang Trong $\& \mathrm{Chu}, 2008)$. However, Combination and Externalization factor are merged together in one factor, and the model could be revised as follows:

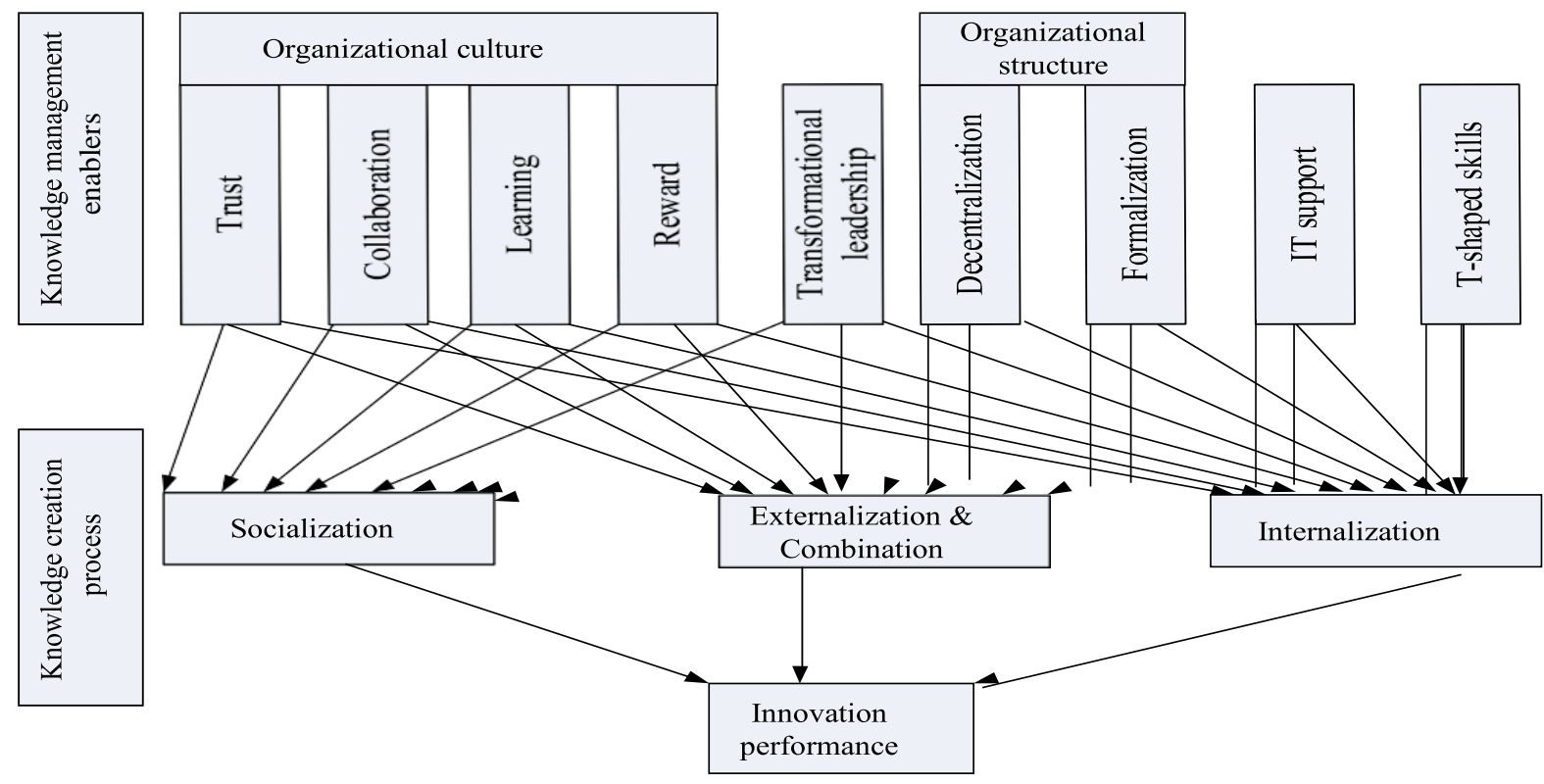

Figure 2. The revised research model 
Therefore, hypothesis H1b-H9b \& H1c-H9c, and H10b \& H10c should be combined together. The revised hypothesis statements would be as follows:

H1bc: Trust has a positive impact on externalization \& combination process

H2bc: Collaboration has a positive impact on externalization \& combination process

H3bc: Learning has a positive impact on externalization \& combination process

H4bc: Reward has a positive impact on externalization \& combination process

H5bc: Transformational leadership has a positive impact on externalization \& combination process

H6bc: Decentralization has a positive impact on externalization \& combination process

H7bc: Formalization has a negative impact on externalization \& combination process

H8bc: IT support has a positive impact on externalization \& combination process

H9bc: T-shaped skills have a positive impact on externalization \& combination process

H1Obc: Externalization \& combination process have a positive impact on innovation performance

\subsection{Regression analysis}

The regression method is Enter method to analyze the relationship between independent factors and dependent factors. The final regression analysis results could be summarized in the following figure.

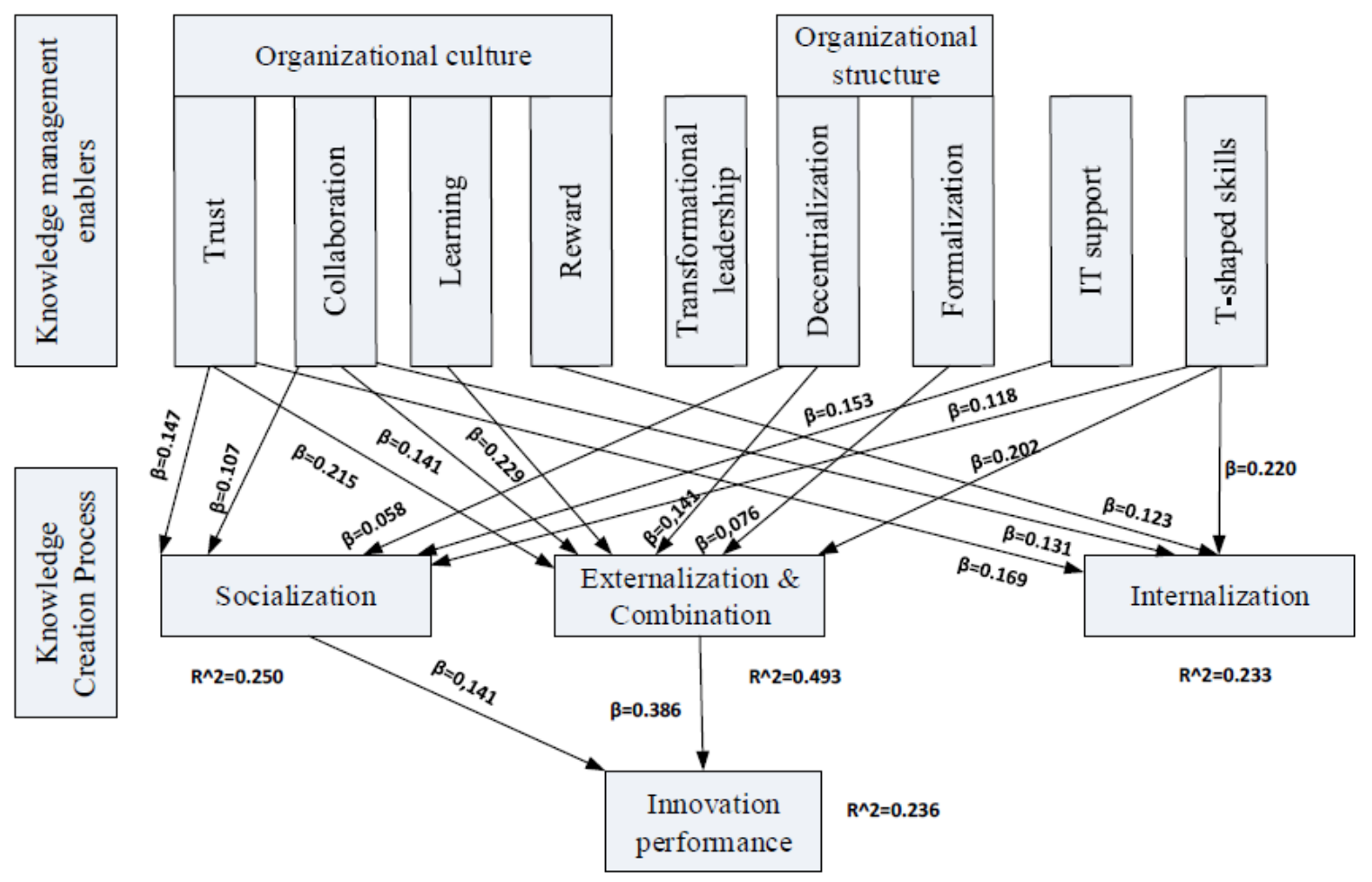

Figure 3. The summarized result of multiple regression analysis 


\subsection{Hypothesis test}

Based on regression analysis result, the conclusion for hypothesis test could be summarized in following table.

\section{Table 5}

Hypothesis evaluation results (Note: significance level $(*):<0.1,(* *):<0.05)$

\begin{tabular}{|c|c|c|c|c|}
\hline Code & Hypothesis & $\begin{array}{l}\text { Standardized } \\
\text { Beta }\end{array}$ & Sig. & Conclusion \\
\hline H1a & Trust $=>$ Socialization & $0.147 * *$ & 0.019 & Supported \\
\hline $\mathrm{H} 2 \mathrm{a}$ & Collaboration $=>$ Socialization & $0.107 *$ & 0.068 & Supported \\
\hline $\mathrm{H} 3 \mathrm{a}$ & Learning $=>$ Socialization & 0.073 & 0.266 & Rejected \\
\hline $\mathrm{H} 4 \mathrm{a}$ & Reward => Socialization & 0.080 & 0.225 & Rejected \\
\hline $\mathrm{H} 5 \mathrm{a}$ & Transformational leadership => Socialization & 0.026 & 0.648 & Rejected \\
\hline H6a & Decentralization $=>$ Socialization & $0.128 *$ & 0.058 & Supported \\
\hline H6a & Decentralization $=>$ Socialization & $0.128 *$ & 0.058 & Supported \\
\hline $\mathrm{H} 7 \mathrm{a}$ & Formalization $=>$ Socialization & -0.038 & 0.502 & Rejected \\
\hline $\mathrm{H} 8 \mathrm{a}$ & IT support => Socialization & $0.153 * *$ & 0.005 & Supported \\
\hline H9a & T-shaped skills => Socialization & $0.118 *$ & 0.059 & Supported \\
\hline H1bc & Trust $=>$ Externalization \& Combination & $0.215 * *$ & 0.000 & Supported \\
\hline $\mathrm{H} 2 \mathrm{bc}$ & $\begin{array}{l}\text { Collaboration } \\
=>\text { Externalization \& Combination }\end{array}$ & $0.141 * *$ & 0.004 & Supported \\
\hline $\mathrm{H} 3 \mathrm{bc}$ & Learning $=>$ Externalization \& Combination & $0.229 * *$ & 0.000 & Supported \\
\hline $\mathrm{H} 4 \mathrm{bc}$ & Reward =>Externalization \& Combination & -0.028 & 0.612 & Rejected \\
\hline $\mathrm{H} 5 \mathrm{bc}$ & $\begin{array}{l}\text { Transformational leadership } \\
=>\text { Externalization \& Combination }\end{array}$ & 0.025 & 0.597 & Rejected \\
\hline H6bc & $\begin{array}{l}\text { Decentralization } \\
=>\text { Externalization \& Combination }\end{array}$ & $0.141 * *$ & 0.011 & Supported \\
\hline $\mathrm{H} 7 \mathrm{bc}$ & $\begin{array}{l}\text { Formalization } \\
=>\text { Externalization \& Combination }\end{array}$ & $0.076 *$ & 0.099 & Supported \\
\hline $\mathrm{H} 8 \mathrm{bc}$ & IT support =>Externalization \& Combination & 0.030 & 0.505 & Rejected \\
\hline $\mathrm{H} 9 \mathrm{bc}$ & $\begin{array}{l}\text { T-shaped skills } \\
=>\text { Externalization \& Combination }\end{array}$ & $0.202 * *$ & 0.000 & Supported \\
\hline H1d & Trust => Internalization & $0.169 * *$ & 0.008 & Supported \\
\hline $\mathrm{H} 2 \mathrm{~d}$ & Collaboration $=>$ Internalization & $0.131 * *$ & 0.027 & Supported \\
\hline $\mathrm{H} 3 \mathrm{~d}$ & Learning => Internalization & 0.029 & 0.660 & Rejected \\
\hline $\mathrm{H} 4 \mathrm{~d}$ & Reward => Internalization & $0.123 *$ & 0.065 & Supported \\
\hline H5d & Transformational leadership $=>$ Internalization & 0.034 & 0.555 & Rejected \\
\hline
\end{tabular}




\begin{tabular}{|c|l|l|l|l|}
\hline Code & \multicolumn{1}{|c|}{ Hypothesis } & $\begin{array}{c}\text { Standardized } \\
\text { Beta }\end{array}$ & Sig. & Conclusion \\
\hline H6d & Decentralization =>Internalization & -0.019 & 0.781 & Rejected \\
\hline H7d & Formalization => Internalization & 0.027 & 0.639 & Rejected \\
\hline H8d & IT support => Internalization & -0.053 & 0.334 & Rejected \\
\hline H9d & T-shaped skills =>Internalization & $0.220 * *$ & 0.001 & Supported \\
\hline H10a & Socialization => Innovation performance & $0.141 * *$ & 0.013 & Supported \\
\hline H10bc & $\begin{array}{l}\text { Externalization \& Combination } \\
\text { => Innovation performance }\end{array}$ & $0.386 * *$ & 0.000 & Supported \\
\hline H10d & Internalization => Innovation performance & 0.025 & 0.656 & Rejected \\
\hline
\end{tabular}

Source: Data analysis result of the research

\subsection{Discussion}

According to the analysis result, the impacts of knowledge management enablers on the knowledge creation process, and then, on innovation performance of SMEs could be confirmed in the context of Lam Dong province, Vietnam. Moreover, the importance and current situation of each enabling factors on the knowledge creation process could be summarized in the following table.

\section{Table 6}

Ranking of impact factors on $\mathrm{KCP}$, and mean of these factors

\begin{tabular}{|l|l|c|c|c|c|c|c|c|}
\hline \multirow{2}{*}{ Code } & \multirow{2}{*}{ Enabling factors } & \multicolumn{2}{|c|}{ Socialization } & \multicolumn{2}{c|}{$\begin{array}{c}\text { Externalization } \\
\text { \& Combination }\end{array}$} & \multicolumn{2}{l}{ Internalization } & \multirow{2}{*}{ Mean } \\
\cline { 3 - 9 } & & $\boldsymbol{\beta}$ & Rank & $\boldsymbol{\beta}$ & Rank & $\boldsymbol{\beta}$ & Rank & \\
\hline H1 & Trust & 0.147 & 2 & 0.215 & 2 & 0.169 & 2 & 4.0585 \\
\hline H2 & Collaboration & 0.107 & 5 & 0.141 & 4 & 0.131 & 3 & 3.7153 \\
\hline H3 & Learning & & & 0.229 & 1 & & & 3.7204 \\
\hline H4 & Reward & & & & & 0.123 & 4 & 3.6322 \\
\hline H5 & $\begin{array}{l}\text { Transformational } \\
\text { leadership }\end{array}$ & & & & & & & 3.7614 \\
\hline H6 & Decentralization & 0.128 & 3 & 0.141 & 4 & & & 3.8578 \\
\hline H7 & Formalization & & & 0.076 & 6 & & & 3.7895 \\
\hline H8 & IT support & 0.153 & 1 & & & & & 2.7283 \\
\hline H9 & T-shaped skills & 0.118 & 4 & 0.202 & 3 & 0.220 & 1 & 3.5175 \\
\hline
\end{tabular}

Source: Data analysis result of the research 
According to this result, only transformational leadership has no impact on KCP. This is different from the result of Berraies et al. (2014), where transformational leadership has a positive impact on socialization and externalization. The reason could be that most of the managers of SMEs in Lam Dong are not familiar with the transformational leadership style, and the impact of leadership on KCP is underestimated in practice. Some studies also showed that most Vietnamese SMEs are family management styles or more suitable for transactional leadership. This could be changed and improved gradually.

In evaluating the impact of KM enablers on socialization, the result of Berraies et al. (2014) showed that reward has the strongest impact (beta=0.784) on socialization, while in this research, IT support has the strongest impact on socialization. This requires Vietnamese SMEs to improve the ICT infrastructure and to take advantage of IT support for improving knowledge sharing between their employees through socialization process.

In evaluating the impact of KM enablers on externalization and combination, the result of Berraies et al. (2014) showed that reward has the strongest impact on externalization and decentralization has the strongest impact on the combination, while in this research, learning has the strongest impact on externalization and combination. This requires Vietnamese SMEs to develop a learning culture for improving knowledge externalization and combination process.

In evaluating the impact of KM enablers on internalization, the result of Berraies et al. (2014) showed that reward has the strongest impact, while in this research, T-shaped skills have the strongest impact. This requires the managers of Vietnamese SMEs should pay more attention to attracting good people and training skills for their employees to support KCP.

Besides, currently, the mean value of IT-support of Vietnamese SMEs is too low (2.728). This illustrates the low level of ICT applications in Vietnamese SMEs. So, managers of Vietnamese SMEs should equip suitable ICT platforms to support communication and collaboration between their employees. Besides, they should pay attention to building a trust environment, because trust contributes a fairly high impact (the $2^{\text {nd }}$ rank) on all phases of KCP.

In general, the $\mathrm{R}^{2}$ coefficient of KCP on innovation performance is 0.236 (fairly low). This means the model could only explain for $23.6 \%$ of the change in innovation performance by $\mathrm{KCP}$, and some other factors impacting on innovation performance have not been included in this model. So, to improve the innovation performance of Vietnamese SMEs, some other approaches should also be considered besides KM approach.

\section{Conclusion \& recommendations}

In general, based on a research model of Berraies et al. (2014), this research tried to explore the impact of knowledge management enablers on knowledge creation processes, and then, on innovation performance of Vietnamese SMEs in Lam Dong province. Based on data analysis, the enabling factors affecting on KCP include: trust, collaboration, learning, reward, decentralization, formalization, IT support, T-shaped skills. KCP, especially externalization and combination process, is confirmed to have a positive impact on the innovation performance of SMEs, but internalization has no significant impact on the innovation performance of Vietnamese SMEs. 
Based on these results, some recommendations for improving knowledge creation processes and innovation performance of Vietnamese SMEs could be suggested as follows:

- Create "Ba" or the knowledge-creating environment according to SECI model to support the knowledge creation process. Especially focusing on externalization and combination process of SECI model because they have the strongest impact on the innovation performance of Vietnamese SMEs. Organizing frequent meetings or seminars within the company will help to encourage employees to share their ideas, experiences, and solutions for various problems, which are very useful for externalization and combination process. As a result, it can support SMEs in creating new knowledge and increasing their innovation performance;

- Learning has the highest impact on the externalization and combination process of $\mathrm{KCP}$. Therefore, developing a learning culture is important for supporting KCP. Some HRM policies related to training \& learning should be revised to encourage the employees to continue to learn during their lives from various forms, such as meetings, courses, e-learning systems, libraries, books, colleagues... Adding some KPIs relating to learning will help to improve productivity and to support the knowledge-creating cycle of SMEs;

- T-shaped skills have the strongest impact on the internalization process of KCP. So, attracting talented people, who have both wide and deep knowledge to support their jobs, is very important. The job description and recruiting process should be changed to be able to recruit good employees who have T-shaped skills. Collaboration with the Universities also helps to improve the skills for current employees and to attract the right candidates with T-shaped skills;

- IT support plays an important role in sharing knowledge between employees, especially in the socialization process of KCP. Therefore, SMEs should apply innovative ICT platforms (hardware/ software) to support communication and collaboration between employees and project members. This will help to make it easy for knowledge sharing between employees, to increase the ICT maturity level, so that, SMEs will be ready for KM solutions;

- Besides, developing a suitable organizational culture, which helps to build trust between employees, is also important to support all phases of KCP. Trust must be developed based on understanding and sympathizing between people in the organization. So, some activities could help to build trust, such as team building, social activities, sport games, parties, etc. should be organized frequently.

However, there are still some limitations of this research, such as small sample size, convenience sampling method, limitation in regression analysis method. Therefore, some implications for future research could be summarized as follows:

- Increasing sample size and apply better sampling method;

- Extending the scope to SMEs in other provinces in Vietnam, or in other countries with similar conditions;

- Applying SEM/ AMOS for analyzing inter-relationship between various factors.

Evaluating the impact of other factors on innovation performance to increase the $\mathrm{R}^{2}$ coefficient. 


\section{References}

Al-Hakim, L. A. Y., \& Hassan, S. (2012). Critical success factors of knowledge management, innovation and organizational performance: An empirical study of the Iraqi mobile telecommunication sector. British Journal of Economics, Finance and Management Sciences, 4(1), 31-49.

Bass, B. M. (1999). Two decades of research and development in transformational leadership. European Journal of Work and Organizational Psychology, 8(1), 9-32. doi:10.1080/135943299398410

Berraies, S., Chaher, M., \& Ben-Yahia, K. (2014). Knowledge management enablers, knowledge creation process and innovation performance: An empirical study in Tunisian information and communication technologies sector. BMS Business Management and Strategy, 5(1), 1. doi:10.5296/bms.v5i1.5465

Bosch, D. (2013). The impact of transformational leadership on leader-follower work value congruence. International Journal of Business and Social Research (IJBSR), 3(8). doi:10.18533/ijbsr.v3i8.269

Charoenngam, C., \& Teerajetgul, W. (2006). Factors inducing knowledge creation: Empirical evidence from Thai construction projects. Engineering, Construction and Architectural Management, 13(6), 584-599. doi:10.1108/09699980610712382

Chatzoudes, D., Chatzoglou, P., \& Vraimaki, E. (2015). The central role of knowledge management in business operations: Developing a new conceptual framework. Business Process Management Journal, 21(5), 1117-1139. doi:10.1108/BPMJ-10-2014-0099

Choi, B., \& Lee, H. (2002). Knowledge management strategy and its link to knowledge creation process. Expert Systems with Applications, 23(3), 173-187. doi:10.1016/S09574174(02)00038-6

Dalkir, K. (2005). Knowledge management in theory and practice. London, UK: Routledge.

Davenport, E., \& Hall, H. (2002). Organizational knowledge and communities of practice. Annual Review of Information Science and Technology, 36(1), 171-227. doi:10.1002/aris.1440360105

Davenport, T. H., \& Prusak, L. (1998). Working knowledge: How organizations manage what they know. Boston, MA: Harvard Business School Press.

Dunk, N., \& Jeng, D. (2013). Knowledge management enablers and knowledge creation in ERP system success. International Journal of Electronic Business Management, 11(1), 49-59.

Gonzalez, A. (2014). SMEs drive world trade and economic growth. Retrieved January 15, 2018, from http://www.intracen.org/news/SMEs-drive-world-trade-and-economicgrowth/

Gururajan, R., \& Hafeez-Baig, A. (2012). Critical role of 'T-Shaped skills \& incentive rewards' as determinants for knowledge management enablers: A case of Indian study. In C. Kalloniatis (Ed.), Modern Information Systems (pp.133-146). London, UK: InTech.

Hoang Trong \& Chu, N. N. M. (2008). Phân tích dũ liệu nghiên cưu với SPSS. [Analyzing research data with SPSS]. Ho Chi Minh, Vietnam: Nhà xuất bản Thống Kê. 
IPP. (2014). Đẩy mạnh đổi mới sáng tạo trong các doanh nghiệp vìa và nhỏ [Promoting innovation in small and medium enterprises]. Retrieved February 18, 2018, from http://doanhnghiepvn.vn/day-manh-doi-moi-sang-tao-trong-cac-doanh-nghiep-nho-vavua-d44582.html

Lee, H., \& Choi, B. (2003). Knowledge management enablers, processes, and organizational performance: An integrative view and empirical examination. Journal of Management Information System, 20(1), 179-228. doi:10.1080/07421222.2003.11045756

Lopez-Nicolas, C., \& Merono-Cerdan, A. L. (2011). Strategic knowledge management, innovation and performance. International Journal of Information Management, 31(6), 502-509. doi:10.1016/j.ijinfomgt.2011.02.003

Maranville, S. (1992). Entrepreneurship in the business curriculum. Journal of Education for Business, 68(1), 27-31. doi:10.1080/08832323.1992.10117582

Migdadi, M. M. (2005). An integrative view and empirical examination of the relationships among knowledge management enablers, processes and organizational performance in Australian enterprises (Unpublished doctoral dissertation). University of Wollongong, Australia.

Nguyen, D. Q. \& Vu, T. H. (2014). Strategic knowledge management, innovation and firm performance: An empirical study in Vietnamese firms. Journal of Economics and Development, 60-73. doi:10.33301/2014.16.01.04

Nguyen, T. D., \& Nguyen, T. T. M. (2007). Nghiên cúu khoa học Marketing úng dụng mô hình cấu trúc tuyến tính SEM [Marketing research is applying SEM linear structure model]. Ho Chi Minh City, Vietnam: NXB Đại học Quốc gia TP.HCM.

Nonaka, I., \& Konno, N. (1998). The concept of 'ba': Building a foundation for knowledge creation. California Management Review, 40(3), 40-54.

Nonaka, I., \& Takeuchi, H. (1995). The knowledge-creating company: How Japanese companies create the dynamics of innovation. Oxford, UK: Oxford University Press.

Nonaka, I., \& Toyama, R. (2005). The theory for the knowledge-creating firm: Subjectivity, objectivity and synthesis. Industrial and Corporate Change, 14(3), 419-436. doi:10.1093/icc/dth058

Nonaka, I., Toyama, R., \& Hirata, T. (2011). Quản trị dụa vào tri thúc [Management is based on knowledge] (V. K. Linh, Trans.). Hanoi, Vietnam: NXB Thời Đại.

Nonaka, I., Toyama, R., \& Konno, N. (2000). SECI, ba and leadership: A unified model of dynamic knowledge creation. Long Range Planning, 33(1), 5-34. doi:10.1016/S00246301(99)00115-6

Pham, T. Q. (2013). Apply KM and SNS for improving labor productivity of Vietnamese SME. Covenant Journal of Informatics and Communication Technology, 1(1), 15-21.

Pham, T. Q. (2016). Giáo trình Quản lý Tri thúc. [Knowledge of Management Curriculum]. Hanoi, Vietnam: NXB Xây Dựng.

Pham, T. Q., \& Hara, Y. (2011). KM approach for improving the labor productivity of Vietnamese enterprises. International Journal of Knowledge Management, 7(3), 27-42. doi:10.4018/jkm.2011070103 
Pham, T. Q., \& Nguyen, T. D. (2017). An empirical investigation of knowledge management in Vietnamese SMEs. Paper presented at The 17th International Conference on Computational Science and Its Applications (ICCSA), Trieste, July 2017, pp. 1-6. doi:10.1109/ICCSA.2017.8000016

Polanyi, M. (1966). The tacit dimension. London, UK: Routledge \& Kegan Paul.

Politis, J. D. (2001). The relationship of various leadership styles to knowledge management. Leadership \& Organization Development Journal, 22(8), 354-364. doi:10.1108/ 01437730110410071

Serban, A. M., \& Luan, J. (2002). Overview of knowledge management. New Directions for Institutional Research, 2002(113), 5-16. doi:10.1002/ir.34

Svetina, A., \& Prodan, I. (2008). How internal and external sources of knowledge contribute to firms' innovation performance. Managing Global Transitions, 6(3), 277-299. 